\title{
Response: Commentary: Evaluating the Role of Seagrass in Cenozoic $\mathrm{CO}_{2}$ Variations
}

\author{
Marco Brandano ${ }^{1,2 *}$, Luis Pomar ${ }^{3}$, Guillem Mateu-Vicens ${ }^{3,4}$, Marco Cuffaro ${ }^{2}$, \\ Giovanni Gaglianone ${ }^{1}$, Patrizio Petricca ${ }^{1}$ and Vincenzo Stagno ${ }^{1}$ \\ ${ }^{1}$ Dipartimento Scienze della Terra, Università Roma La Sapienza, Rome, Italy, ${ }^{2}$ Istituto di Geologia Ambientale e \\ Geoingegneria (CNR), Sez. Sapienza, Dipartimento Scienze della Terra, Università Roma La Sapienza, Rome, Italy, ${ }^{3}$ Càtedra \\ Guillem Colom Casasnovas, Universitat de les Illes Balears, Palma de Mallorca, Spain, ${ }^{4}$ Laboratorio de Zoología, \\ Departament de Biologia, Universitat de les Illes Balears, Palma de Mallorca, Spain
}

Keywords: biocalcification, seagrass, $\mathrm{CO}_{2}$, carbonate, biosequestration

\section{A commentary on}

OPEN ACCESS

Edited by:

Cody Sheik,

University of Minnesota Duluth,

United States

Reviewed by:

Hildegard Westphal,

Leibniz Centre for Tropical Marine

Research (LG), Germany

*Correspondence:

Marco Brandano

marco.brandano@uniroma1.it

Specialty section

This article was submitted to

Microbiological Chemistry and

Geomicrobiology,

a section of the journal

Frontiers in Environmental Science

Received: 01 September 2017

Accepted: 19 October 2017

Published: 07 November 2017

Citation:

Brandano M, Pomar L,

Mateu-Vicens G, Cuffaro M,

Gaglianone G, Petricca P and

Stagno V (2017) Response:

Commentary: Evaluating the Role of

Seagrass in Cenozoic $\mathrm{CO}_{2}$ Variations.

Front. Environ. Sci. 5:74.

doi: 10.3389/fenvs.2017.00074
Commentary: Evaluating the Role of Seagrass in Cenozoic $\mathrm{CO}_{2}$ Variations

by Macreadie, P. I., Serrano, O., Duarte, C. M., Beardall, J., and Maher, D. (2017). Front. Environ. Sci. 5:55. doi: 10.3389/fenvs.2017.00055

We would like to acknowledge Macreadie et al. (2017) for their interest in clarifying some key points on the processes involved in the balance of $\mathrm{CO}_{2}$ exerted by the seagrass ecosystems during the Cenozoic. However, their criticisms seem to be based on some misunderstandings regarding the biocalcification processes. So we take this opportunity to make clear some concepts on this topic.

Macreadie et al. (2017) criticize Brandano et al. (2016) when considering the epiphytic carbonate production to result in net $\mathrm{CO}_{2}$ sequestration, in addition to the $\mathrm{CO}_{2}$ sequestration by the growth of the seagrasses. In fact, they assert "the authors have not accounted for the fact that calcification increases $\mathrm{pCO}_{2}$ (by depleting $\mathrm{CO}_{3}^{-2}$ and therefore reducing alkalinity), which facilitates the return of $\mathrm{CO}_{2}$ to the atmosphere. Specifically, for every mole of $\mathrm{CaCO}_{3}$ precipitated as carbonate, the process also consumes 2 moles of $\mathrm{HCO}_{3}^{-}$and releases 1 mole of $\mathrm{CO}_{2}$ ".

This criticism is clearly questionable and contradicts themselves (Macreadie et al., 2014) when considered the $\mathrm{C}$ to be stored by the seagrass system not only in the organic tissues (leaves, roots and rhizomes) but also in the inorganic skeletons (carbonates). In fact they wrote "...carbonates even though they are inorganic, and carbonate formation releases net $\mathrm{CO}_{2}-$ should be included as part of the $C$ stock because they consist of bound $C$ that is locked away, and might otherwise end up as $\mathrm{CO}_{2}$ in the atmosphere."

The seagrass ecosystem uses the $\mathrm{CO}_{2}$ in two main processes: in the photosynthetic production of the organic tissues -leafs, roots and steams, as well as the organic parts of all associated organisms that live in this ecosystem, and in the carbonate precipitation forming skeletons of the epiphytic biotas. In both processes, the DIC $\left(\mathrm{CO}_{2}\right.$ and $\left.\mathrm{HCO}_{3}^{-}\right)$is used. The organic matter is only a temporary sink of the $\mathrm{CO}_{2}$ because after death and decay the $\mathrm{CO}_{2}$ returns to the atmosphere.

It is well-known that photosynthetic prokaryotes since the Archean, prokaryotes and eukaryotes during the Proterozoic, and more evolved forms of photosynthetic life also during the Phanerozoic have been using the $\mathrm{CO}_{2}$ derived from the Earth Mantle outgassing. Nevertheless, following the Great Oxidation Event, around $2000 \mathrm{Ma}$ ago, the oxygen started to accumulate in the atmosphere and dissolved in the oceans. This reverted the reaction and the organic matter that was not buried (isolated from the oxidizing environments) became oxidized and the carbon returned to 
the atmosphere in the form of $\mathrm{CO}_{2}$ (1). But, if organic matter is buried, it is isolated from oxidizing processes and becomes a real sink of $\mathrm{C}$, as represented by are the hydrocarbon and coal deposits.

$$
\mathrm{H}_{2} \mathrm{O}+\mathrm{CO}_{2}<->\mathrm{CH}_{2} \mathrm{O}+\mathrm{O}_{2}
$$

In alkaline waters, bicarbonate is the most abundant DIC species, but it is inaccessible without a source of protons (2). Diffusion from ambient waters can supply protons that are consumed during photosynthesis. But as diffusion is slow, the $\mathrm{CO}_{2}$ becomes depleted, photosynthesis is inhibited and the photosynthetic organisms are bathed in an alkaline microenvironment. By discharging the protons from calcification into their boundary layers (2) and Figure 1, photosynthetic organisms can maintain or even elevate $\mathrm{CO}_{2}$ concentrations despite photosynthetic $\mathrm{CO}_{2}$ uptake (3). This enhances carboxylation efficiencies (McConnaughey and Whelan, 1997; Pomar and Hallock, 2008).

$$
\begin{array}{r}
\mathrm{Ca}^{++}+\mathrm{HCO}_{3}^{-}->\mathrm{CaCO}_{3}+\mathrm{H}^{+} \\
\mathrm{H}^{+}+\mathrm{HCO}_{3}^{-}->\mathrm{CH}_{2} \mathrm{O}+\mathrm{O}_{2}
\end{array}
$$

Adding reactions (2) and (3) one obtains a $1: 1$ ratio of calcification to photosynthesis in which both calcification and organic matter are part of the same system.

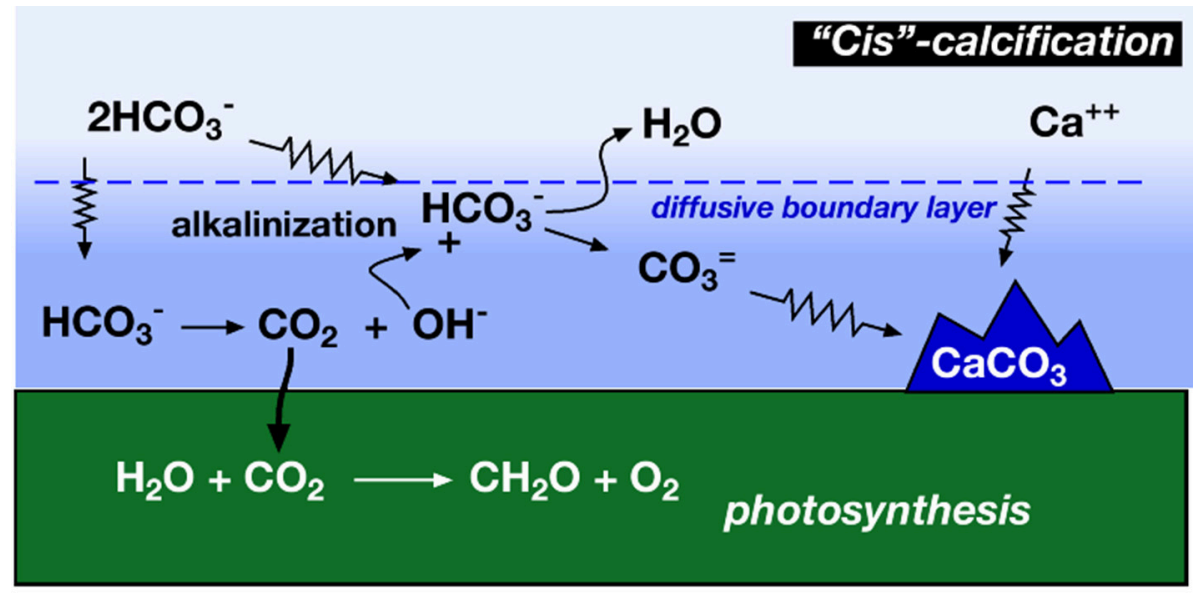

"Trans"-calcification ATPase pumps

does not require photosynthesis

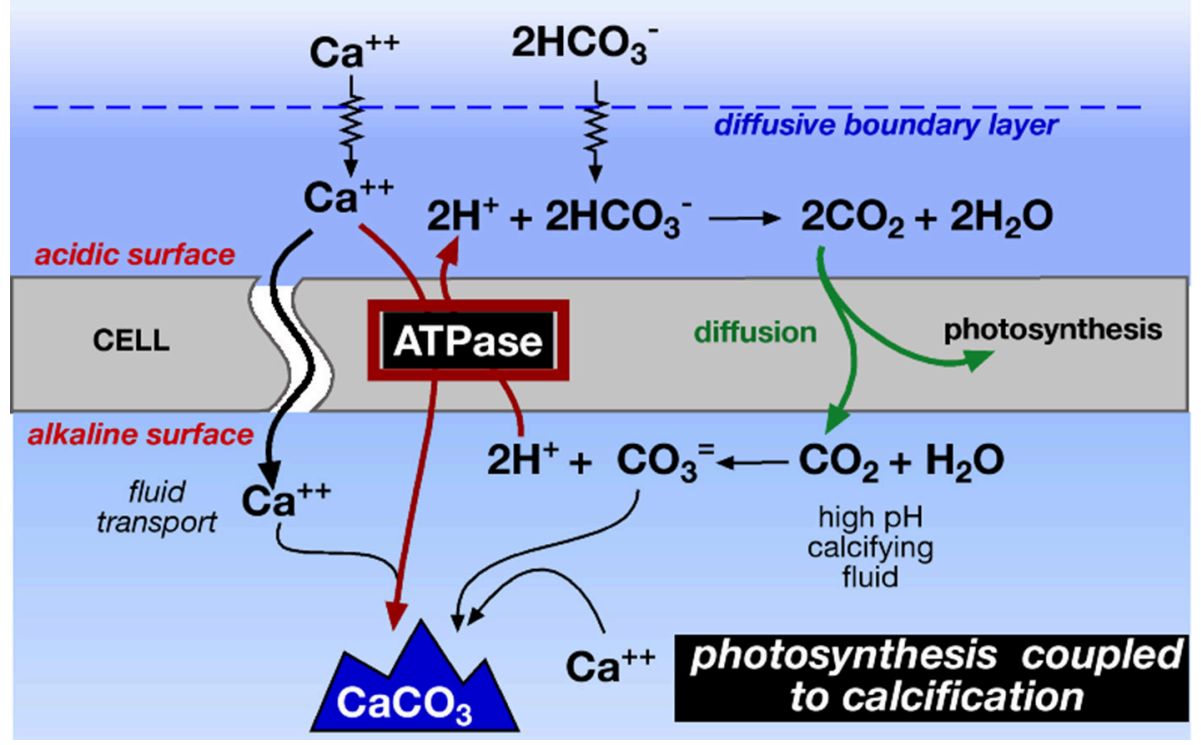

FIGURE 1 | "Cis" and "trans" calcification mechanisms. Photosynthetic alcalinization of the water causes cis calcification, while enzyme Ca ${ }^{++}$ATPase drives the $\mathrm{Ca}^{++} / 2 \mathrm{H}^{+}$exchange in the trans calcification (redrawn from McConnaughey and Whelan, 1997). Cis calcification occurs on the same side of the photosynthetic carbon uptake, whereas trans calcification occurs away of the site of carbon uptake. 


$$
\mathrm{Ca}^{++}+2 \mathrm{HCO}_{3}^{-}->\mathrm{CaCO}_{3}+\mathrm{CH}_{2} \mathrm{O}+\mathrm{O}_{2}
$$

The $\mathrm{CaCO}_{3}$ accumulates in the lithosphere, being the limestones and dolostones a permanent storage form of $\mathrm{CO}_{2}$. The same applies to the skeletons of calcifying organisms. The only process releasing the $\mathrm{CO}_{2}$ trapped in the carbonate rocks is the recycling of the lithosphere in the subduction zones and the associated volcanism.

When Macreadie et al. (2017) use the reaction (5) to illustrate calcification as a source of $\mathrm{CO}_{2}$, they ignore the stoichiometry of the complete system (6):

$$
\begin{array}{r}
\mathrm{Ca}^{++}+2 \mathrm{HCO}_{3}^{-}->\mathrm{CaCO}_{3}+\mathrm{H}_{2} \mathrm{O}+\mathrm{CO}_{2} \\
2 \mathrm{CO}_{2}+2 \mathrm{H}_{2} \mathrm{O}<->2 \mathrm{H}_{2} \mathrm{CO}_{3}<->2 \mathrm{H}^{+}+2 \mathrm{HCO}_{3}^{-}
\end{array}
$$

As it is obvious, to release one $\mathrm{CO}_{2}$ from carbonate precipitation (5), two $\mathrm{CO}_{2}$ are needed to produce the two required bicarbonates (6). So, the balance of the carbonate precipitation is a net $\mathrm{CO}_{2}$ sink. This is well illustrated in the different calcification processes (Figure 1)

Macreadie et al. (2017) opinion that calcification represents a global $\mathrm{CO}_{2}$ source to the atmosphere, and therefore seagrass meadows could represent a significant net $\mathrm{CO}_{2}$ source is just the vision of one half of the processes, and cannot be sustained when looking at the entire carbon cycle.

\section{REFERENCES}

Brandano, M., Cuffaro, M., Gaglianone, G., Pettricca, P., Stagno, V., and MateuVicens, G. (2016). Evaluating the role of seagrass in Cenozoic $\mathrm{CO}_{2}$ variations. Front. Environ. Sci. 4:72. doi: 10.3389/fenvs.2016.00072

Fourqurean, J. W., Duarte, C. M., Kennedy, H., Marbà, N., Holmer, M., Mateo, M. A., et al. (2012). Seagrass ecosystems as a globally significant carbon stock. Nature Geosci. 5: 505-509. doi: 10.1038/ngeo1477

Macreadie, P. I., Baird, M. E., Trevathan-Tackett, S. M., Larkum, A. W. D., and Ralph, P. J. (2014). Quantifying and modelling the carbon sequestration capacity of seagrass meadows: a critical assessment. Mar. Pollut. Bull. 83, 430-439. doi: 10.1016/j.marpolbul.2013.07.038

Macreadie, P. I., Serrano, O., Duarte, C. M., Beardall, J., and Maher, D. (2017). Commentary: Evaluating the Role of Seagrass in Cenozoic $\mathrm{CO}_{2}$ Variations. Front. Environ. Sci. 5:55. doi: 10.3389/fenvs.2017.00055

Mateo, M. A., and, O., Serrano (2012). The Carbon Sink Associated to Posidonia oceanica. Switzerland and Málaga: IUCN, Gland.
As result of these biased misconceptions, the authors enter in continuous contradictions. Their estimations from Mediterranean case histories made them to conclude that calcification in $P$. oceanica meadows could be responsible for

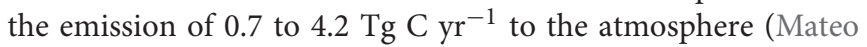
and Serrano, 2012). So why are people promoting to restore and protect $P$. oceanica meadows, in order to fulfill their key role in carbon cycle and storage by adopting efficient regulation of human pressures such as fishing? Some of the coauthors of the Macreadie et al. (2017) commentary (e.g., Fourqurean et al., 2012) state that the rapid loss of seagrasses resulted in a substantial decrease in $\mathrm{C}$ sequestration by seagrass ecosystems of

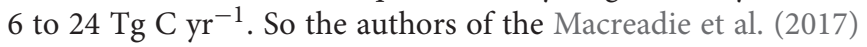
paper have to take a decision: are seagrasses a sink or a source of $\mathrm{CO}_{2}$ ? If they conclude seagrasses are a source, then we should review the entire evolution of Earth and Life.

\section{AUTHOR CONTRIBUTIONS}

MB, LP, and GM led the paper. All authors contributed to the discussion.

\section{ACKNOWLEDGMENTS}

Criticisms by reviewer Hildegard Westphal and Associate Editor Cody Sheik greatly improved the manuscript.

McConnaughey, T. A., and Whelan, J. F. (1997). Calcification generates protons for nutrient and bicarbonate uptake. Earth Sci. Rev. 42, 95-117.

Pomar, L., and Hallock, P. (2008). Carbonate factories: a conundrum in sedimentary geology. Earth Sci. Rev. 87, 134-169. doi: 10.1016/j.earscirev.2007.12.002

Conflict of Interest Statement: The authors declare that the research was conducted in the absence of any commercial or financial relationships that could be construed as a potential conflict of interest.

Copyright (C) 2017 Brandano, Pomar, Mateu-Vicens, Cuffaro, Gaglianone, Petricca and Stagno. This is an open-access article distributed under the terms of the Creative Commons Attribution License (CC BY). The use, distribution or reproduction in other forums is permitted, provided the original author(s) or licensor are credited and that the original publication in this journal is cited, in accordance with accepted academic practice. No use, distribution or reproduction is permitted which does not comply with these terms. 